\title{
Large moderately-differentiated ovarian Sertoli-Leydig cell tumor in a 13-year-old female: A case report
}

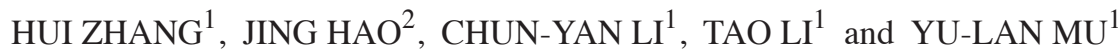 \\ ${ }^{1}$ Department of Obstetrics and Gynecology, Shandong Provincial Hospital Affiliated to Shandong University; \\ ${ }^{2}$ Department of Histology and Embryology, Medical School of Shandong University, Jinan, Shandong 250012, P.R. China
}

Received August 28, 2014; Accepted May 27, 2015

DOI: 10.3892/ol.2015.3979

\begin{abstract}
Sertoli-Leydig cell tumor of the ovary, also known as androblastoma, is a rare neoplasm from the group of sex cord-stromal tumors of the ovary. The tumor accounts for $<0.5 \%$ of all primary ovarian neoplasms. The clinical signs and symptoms of Sertoli-Leydig cell tumors can be associated with either hormonal production or the presence of a mass-occupying lesion. In the current study, a 13-year-old female was diagnosed with a stage Ic ovarian Sertoli-Leydig cell tumor following abdominal pain and distension. One month after a right oophorectomy, the follow-up magnetic resonance imaging scan was negative for residual or recurrent tumor. The overall 5-year survival rate for moderately-differentiated (grade 2) and poorly-differentiated (grade 3) Sertoli-Leydig cell tumors is $80 \%$, and long-term follow-up is therefore highly advised in this patient.
\end{abstract}

\section{Introduction}

Sertoli-Leydig cell tumor of the ovary, also known as androblastoma, is a rare neoplasm from the group of sex cord-stromal tumors of the ovary. The tumor accounts for $<0.5 \%$ of all primary ovarian neoplasms (1), with a median age at diagnosis of 25 years (2). The clinical signs and symptoms of Sertoli-Leydig cell tumors can be associated with either hormonal production or the presence of a mass-occupying lesion. Thyroid enlargement with decreased thyroid-stimulating hormone (TSH) levels and clitoral hypertrophy is rare. Notably, the most serious surgical complication of hyperthyroid crisis, which is caused by the tumor, and all the endocrine symptoms will disappear once the tumor is removed. In a study of 207 cases, the majority of the tumors

Correspondence to: Professor Yu-Lan Mu, Department of Obstetrics and Gynecology, Shandong Provincial Hospital Affiliated to Shandong University, 324 Jingwu Weiqi Road, Jinan, Shandong 250012, P.R. China

E-mail: yulanmu@gmail.com

Key words: ovary, Sertoli-Leydig cell tumor, hyperthyroidism, masculinization reported were unilateral and confined to the right ovary (3), with an average size of $13.5 \mathrm{~cm}$ (1). The management of Sertoli-Leydig cell tumors remains challenging due to lack of standardized management protocol guidelines (4). The current study presents the case of a young female patient with a large moderately-differentiated ovarian Sertoli-Leydig cell tumor.

\section{Case report}

A 13-year-old female presented to the Shandong Provincial Hospital affiliated to Shandong University (Jinan, Shandong, China) with a 7-day history of abdominal distension, a 3-day history of abdominal pain and a pelvic mass. Systemic review was remarkable for intermittent constipation for two years, hoarseness of the voice for two months and menstrual irregularities for one year. The patient's last menstruation was three months previously. The patient weighed $57 \mathrm{~kg}$, with a height of $164 \mathrm{~cm}$. The heart rate was 102 beats/min (normal range, $60-100$ beats/min) and the blood pressure was $119 / 85 \mathrm{mmHg}$ (normal, 110/70 $\mathrm{mmHg}$ ). The basal metabolism was $25 \%$ [basal metabolic rate $\%=$ (pulse rate + pulse pressure $)-111$ ] indicting mild hyperthyroidism. A physical examination revealed enlargement of the thyroid gland, acne and a large abdominal mass. The upper boundary of the mass was the xiphoid process and the lower boundary was the pubic symphysis. Hypertrophy of the clitoris was also observed.

Laboratory tests were performed that showed increased total serum levels of testosterone at $1.64 \mathrm{ng} / \mathrm{ml}$ (normal range, $0.35-0.72 \mathrm{ng} / \mathrm{ml}$ ), dehydroepiandrosterone sulfate at $8.52 \mu \mathrm{mol} / 1$ (normal range, 1.48-6.92 $\mu \mathrm{mol} / \mathrm{l}$ ) and cancer antigen (CA)-125 at $109.3 \mathrm{U} / \mathrm{ml}$ (normal range, 0-39 U/ml), and an increased erythrocyte sedimentation rate of $42 \mathrm{~mm} / \mathrm{h}$ (normal range, $0-20 \mathrm{~mm} / \mathrm{h}$ ). The free thyroxine level was elevated to $9.03 \mathrm{pmol} / 1$ (normal range, 3.5-6.5 pmol/1) and the free triiodothyronine level was normal at $17.02 \mathrm{pmol} / 1$ (normal range, $11.5-22.7 \mathrm{pmol} / \mathrm{l})$. However, the TSH level was markedly reduced to $0.099 \mu \mathrm{IU} / \mathrm{ml}$ (normal range, 0.51-4.94 $\mu \mathrm{IU} / \mathrm{ml}$ ). Ultrasonography examination revealed a huge, cystic mass with multiple echo space and thyroid nodules.

During surgery, $200 \mathrm{ml}$ yellow ascites was noted and cytological examination of the ascites showed no tumor cells. The mass was a cyst that originated from the right ovary with a 5-mm rupture (Fig. 1). The uterus, right fallopian tube and left ovary showed no evident abnormalities. A right oophorectomy 


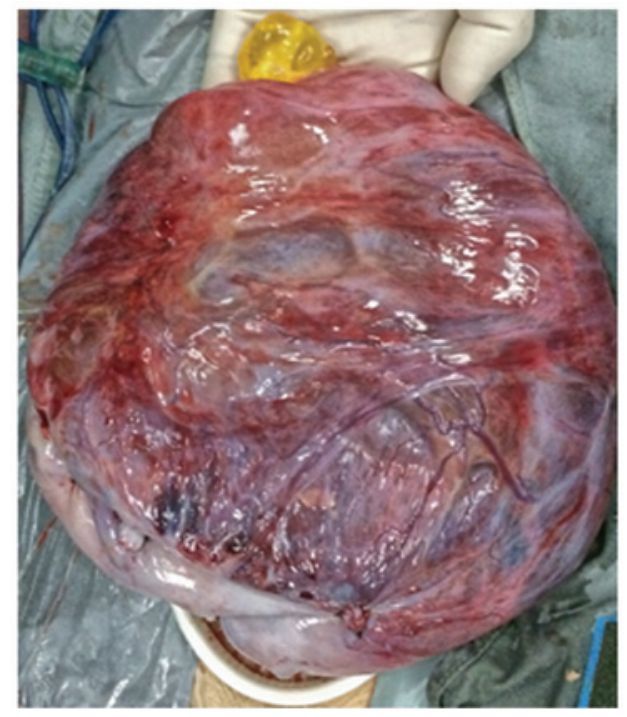

Figure 1. Ovarian mass (cyst fluid has been partially drained).

was performed in May 2015 and the pathological examination showed a $35 \times 25 \times 12-\mathrm{cm}$ Sertoli-Leydig cell tumor of the right ovary with intermediate differentiation [stage Ic according to FIGO 2009 staging system for ovarian cancer (5)]. All the laboratory tests were repeated three days after the surgery and returned normal results. Adjuvant chemotherapy was recommended, however, the patient's parents refused this option. During a follow-up examination performed one month after surgery (June 2015), all the laboratory tests were normal. Magnetic resonance imaging scan was negative for residual or recurrent tumor. Menstruation was restored on postoperative day 19. The patient's voice became more feminine, the acne was significantly reduced and the clitoral hypertrophy showed no progression. In addition, the serum CA-125 level and other endocrine test results were also normal.

Written informed consent was obtained from the patient's family for publication of this case study and any accompanying images.

\section{Discussion}

Sertoli-Leydig cell tumors are rare neoplasms belonging to the group of sex cord-stromal tumors of the ovary, and accounting for $<0.5 \%$ of all primary ovarian neoplasms (1). The tumors occur in patients between the ages of 25-30 years, with an average age at diagnosis of 25 years. The tumors are usually unilateral and small, measuring $<5 \mathrm{~cm}$ in diameter (6). Clinical attention is bestowed on half of these cases due to the progressive masculinization caused $(7,8)$.

In the current case, the signs of virilization in the young female patient indicated a hyperandrogenic state, which aroused the suspicion of a virilizing tumor. In a patient with elevated levels of androgens and signs of virilization, a careful gynecological examination is essential to rule out an androgen-producing tumor of the ovaries (7). The presence of elevated androgen levels with a normal DHEA level in the serum can exclude an adrenal androgen-producing tumor (9).

The majority of Sertoli-Leydig cell tumors are small and are occasionally difficult to be identified by radiological imaging $(10,11)$. Transvaginal ultrasound is reported to be the most sensitive method for the detection of an ovarian tumor (9). In the current case, a physical examination revealed a huge abdominal mass with an upper boundary at the xiphoid process and a lower boundary at the pubic symphysis. Ultrasonography examination revealed a large cystic mass with multiple echo space and thyroid nodules.

During surgery, pathological examination showed the presence of a $35 \times 25 \times 12-\mathrm{cm}$ Sertoli-Leydig cell tumor of the right ovary with intermediate differentiation. The tumor was large enough to be noted by the patient or the patient's family, however, the tumor was not found in a timely manner. Thus, routine physical examinations are also important for adolescent girls.

In total, $<10 \%$ of Sertoli-Leydig cell tumors occur prior to menarche or following menopause $(1,12,13)$. Poorly-differentiated tumors are more often found in younger patients $(1,13)$. In the present patient, the pathological examination showed a Sertoli-Leydig cell tumor with intermediate differentiation.

The current case was stage Ic according to FIGO 2009 staging system for ovarian cancer (5) and adjuvant chemotherapy was recommended. The prognosis of ovarian Sertoli-Leydig cell tumors is significantly correlated with the degree of tumor differentiation and the tumor extent. The overall 5-year survival rate for moderately-differentiated (grade 2) and poorly-differentiated (grade 3) Sertoli-Leydig cell tumors is $80 \%$ (14). Long-term follow-up is highly advised in such patients.

\section{Acknowledgements}

This study was supported by grants from the National Natural Science Foundation of China (nos. 81270661 and 81300468).

\section{References}

1. Young RH and Scully RE: Ovarian Sertoli-Leydig cell tumors. A clinicopathological analysis of 207 cases. Am J Surg Pathol 9: 543-569, 1985.

2. Abu-Zaid A, Azzam A, Alghuneim LA, Metawee MT, Amin T and Al-Hussain TO: Poorly differentiated ovarian sertoli-leydig cell tumor in a 16-year-old single woman: A case report and literature review. Case Rep Obstet Gynecol 2013: 858501, 2013.

3. Weng CS, Chen MY, Wang TY, Tsai HW, Hung YC, Yu KJ, Chiang YC, Lin $\mathrm{H}, \mathrm{Lu} \mathrm{CH}$ and Chou HH: Sertoli-Leydig cell tumors of the ovary: A Taiwanese Gynecologic Oncology Group study. Taiwan J Obstet Gynecol 52: 66-70, 2013.

4. Bhat RA, Lim YK, Chia YN and Yam KL: Sertoli-Leydig cell tumor of the ovary: Analysis of a single institution database. J Obstet Gynecol Res 39: 305-310, 2013.

5. FIGO Committee on Gynecologic Oncology: Current FIGO staging for cancer of the vagina, fallopian tube, ovary, and gestational trophoblastic neoplasia. Int J Gynaecol Obstet 105: 3-4, 2009.

6. Garzo VG and Dorrington JH: Aromatase activity in human granulosa cellsduring follicular development and the modulation by follicle-stimulatinghormone and insulin. Am J Obstet Gynecol 148: 657-662, 1984.

7. Rossing M, Gerdes AM, Juul A, Rechnitzer C, Rudnicki M, Nielsen FC and Vo Hansen T: A novel DICER1 mutation identified in a female with ovarian Sertoli-Leydig cell tumor and multinodular goiter: A case report. J Med Case Rep 8: 112, 2014.

8. Moghazy D, Sharan C, Nair M, Rackauskas C, Burnette R, Diamond M, Al-Hendy O and Al-Hendy A: Sertoli-Leydig cell tumor with unique nail findings in a post-menopausal woman: A case report and literature review. J Ovarian Res 7: 83, 2014. 
9. HillDA,Ivanovich J, Priest JR, Gurnett CA, Dehner LP, Desruisseau D, Jarzembowski JA, Wikenheiser-Brokamp KA, Suarez BK, Whelan AJ, et al: DICER1 mutations in familial pleuropulmonary blastoma. Science 325: 965, 2009.

10. Rio Frio T, Bahubeshi A, Kanellopoulou C, Hamel N, Niedziela M, SabbaghianN, Pouchet C, Gilbert L, O'Brien PK, Serfas K, et al DICER1 mutations in familial multinodular goiter with and without ovarian Sertoli-Leydig cell tumors. JAMA 305: 68-77, 2011.

11. Dehner LP, Jarzembowski JA and Hill DA: Embryonal rhabdomyosarcoma of the uterine cervix: A report of 14 cases and a discussion of its unusual clinicopathological associations. Mod Pathol 25: 602-614, 2012
12. Zaloudek $\mathrm{C}$ and Norris HJ: Sertoli-Leydig tumors of the ovary. A clinicopathologic study of 64 intermediate and poorly differentiated neoplasms. Am J Surg Pathol 8: 405-418, 1984.

13. Roth LM, Anderson MC, Govan AD, Langley FA, Gowing NF and Woodcock AS: Sertoli-Leydig cell tumors: A clinicopathologic study of 34 cases. Cancer 48: 187-197, 1981

14. Sigismondi C, Gadducci A, Lorusso D, Candiani M, Breda E, Raspagliesi F, Cormio G, Marinaccio M and Mangili G: Ovarian Sertoli-Leydig cell tumors. A retrospective MITO study. Gynecol Oncol 125: 673-676, 2012. 